\title{
O JUDEU NA LITERATURA PARA CRIANÇAS E JOVENS: UMA LEITURA COM HISTÓRIA
}

\author{
Pedro d'Alte \\ Doutorando em Estudos da Criança pela Universidade do Minho \\ pedrogabrielreis@gmail.com
}

\section{RESUMO}

A diegese d'O caderno do avô Heinrich dá a conhecer uma personagem que migra por força da perseguição cultural e religiosa. Heinrich refugia-se, nos últimos anos da sua vida, em Portugal. A referência narrativa desperta, desde logo, a curiosidade pela possível relação entre a fé judaica e o espaço geográfico português. Por outro lado, sendo tão breve, a mesma narrativa oculta todo o tecido histórico que se entretece entre 'Portugal' e o 'Judaísmo'. Porque merecedor de atenção académica, o trabalho que aqui se apresenta pretende ler os imagótipos judaicos presentes em narrativas para jovens - em articulação com a historiografia portuguesa -, com o intuito de relembrar e de tornar visível este rico património histórico.

Palavras-chave: imagologia literária judaica, representações do judeu na literatura para crianças e jovens, historiografia portuguesa sobre judeus, antissemitismo.

\section{ABSTRACT}

The diegese $O$ caderno do avô Henrich unveils a character who migrates due to both cultural and religious persecution. Heinrich takes refuge in Portugal in the latest part of his life. The narrative awakens, first and foremost, a curiosity about a possible relationship between the Jewish faith and the Portuguese geographical space. On the other hand, as it's such a brief book, it hides all of the historical fabric that entwines both 'Portugal' and 'Judaism'. Because the latter topic deserves a deeper academic attention, this work intends to read the Jewish imagology portrayed in narratives for young people in articulation with the Portuguese historiography. The intention is to remember and to make visible this rich historical patrimony.

Keywords: jewish imagology portrayed in literature, representations of the Jew in children's literature, Portuguese historiography about Jews, anti-semitism. 
A diegese d'O caderno do avô Heinrich dá a conhecer uma personagem que migra por força da perseguição cultural e religiosa. Heinrich refugia-se, nos últimos anos da sua vida, em Portugal. A referência narrativa desperta, desde logo, a curiosidade pela possível relação entre a fé judaica e o espaço geográfico português. Por outro lado, sendo tão breve, a mesma oculta todo o tecido histórico que se entretece entre 'Portugal' e o 'Judaísmo'. Porque merecedor de atenção académica, o trabalho que aqui se apresenta pretende ler os imagótipos judaicos presentes em narrativas para jovens - em articulação com a historiografia portuguesa -, com o intuito de relembrar e de tornar visível este rico património histórico.

\section{O antissemitismo lido entre a Literatura e a História}

Ao longo da Idade Média, o judeu foi sendo tipificado como 'infiel', 'cego' e 'surdo'. Esta política de subjugação, que foi essencial ao reforço da fé cristã, recuperou atitudes antijudaicas. A ideologia em apreço culpou os judeus pelo deicídio, pelo não reconhecimento da virtude messiânica de Jesus Cristo, pela consequente negação da sua divindade e declarou, ainda, os judeus como inimigos da Fé por não aceitarem o dogma da Trindade e da Encarnaçãoii.

Algumas narrativas para jovens recuperam a experiência do Holocausto e permitem perceber que a História "se repete" em diferentes tempos. Atente-se que n'O rapaz do caixote de madeira ${ }^{i i i}$, Leib Lejzon, personagem principal que vive na cidade polaca de Narewka, relata a referida animosidade entre cristãos e judeus e recupera o estigma destacado nas linhas anteriores: 
Havia cerca de mil judeus em Narewka. (...) Em termos gerais, cristãos e judeus viviam lado a lado em harmonia em Narewka, embora eu tivesse aprendido desde cedo que estava a forçar a sorte se passeasse pelas ruas com a minha habitual despreocupação durante a Semana Santa, a semana anterior à Páscoa. Essa era a única ocasião em que os nossos vizinhos cristãos nos tratavam de modo diferente, como se nós, judeus, nos tivéssemos transformado de repente em seus inimigos. Mesmo alguns dos meus companheiros de brincadeira se tornavam meus agressores. Atiravam-me pedras e chamavam-me nomes que eram cruéis e dolorosos, nomes como "assassino de Cristo» (LEYSON, 2013, p. 22-23).

Em contextos de clivagem religiosa, o judeu e o cristão, porque diferentes, leemse, mutuamente, como o outro, num poderoso jogo de imagens ${ }^{\mathrm{iv}}$. Note-se que tanto o cristianismo como o judaísmo condicionam o quotidiano dos seus praticantes, sendo que a adoção de práticas religiosas dissemelhantes é, facilmente, percecionada. A personagem enfocada partilha a mesma opinião: "Éramos uma população rural, pouco sofisticada e muito trabalhadora, tanto judeus como cristãos, cujas vidas giravam à volta da família, dos nossos calendários religiosos e das estações de semeadura e colheita" (idem, p. 27).

O relato de Lejzon fornece importantes registos sobre a árdua convivência entre cristãos e judeus, assim como sobre a segregação existente na Polónia de 1930. Em relação a este tópico, o judeu regista: "o catolicismo era a religião dominante da Polónia, e a religião era uma parte importante da escola pública que eu frequentava. Quando os meus colegas católicos recitavam suas orações, nós, os judeus, éramos obrigados a ficar em pé e em silêncio" (LEYSON, 2013, p. 25). Mesmo quando terminada a guerra, a religião continuará a ser um traço identitário presente na autoimagem de cada comunidade: "muitos anos depois voltei a Narewka. Um polaco gentio (...) contou-me como um jovem 
judeu tentara fugir, mas, como ele disse, «um dos nossos» - por outras palavras, um nãojudeu - vira-o e denunciara-o às SS" (idem, p. 139) .

Também n'O caderno do avô Heinrich existe a consciência da diferença, tanto ao nível da fisionomia como das práticas religiosas: "O Józef tinha o nariz adunco e a pela morena, como muitos dos judeus do bairro onde morávamos, e conviç̧ões religiosas muito diferentes das da minha família" (Tomé, 2013, p. 27). No entanto, nesta obra, são enaltecidas características humanas positivas no que tange a relação com a diferença. A seguir ao recorte destacado, pode ler-se: “A minha mãe dizia que, em relação aos amigos, o que realmente interessa é a forma como nos dão a mão ou um abraço nos dias difíceis. E que apenas nesses dias é que se confirmam os verdadeiros amigos" (Tomé, 2013, p. 27).

Progressivamente, as narrativas realçadas começam a desenhar uma cartografia cultural e permitem ler a progressão da relação entre judeus e não-judeus assim como a intensificação da tensão entre fações.

\section{Diálogos de força: o judeu na periferia da sociedade}

Em ambos os cenários literários, a população judaica negoceia com os eixos de poder numa posição desfavorecida, isto é, os seguidores de Moisés são uma minoria populacional e religiosa dentro de um quadro social mais amplo e, potencialmente, antagónico. Nesta lógica, o povo de Moisés fica especialmente vulnerável às vontades populacionais, às decisões governativas tomadas, às danças nas cadeiras do poder.

No passado, exemplos destas situações são recorrentes. O período das grandes cruzadas propiciou uma tomada de força generalizada e motivada contra os inimigos da 
fé cristã. Estes fluxos de dominância fixaram como alvos o muçulmano, mas também o judeu. Poliakov defende que, durante o séc. XIV, o antissemitismo alastrou na Europa: "os ódios antijudaicos atingem uma tal acuidade que podemos ousadamente datar esta época como a cristalização do antissemitismo em sua forma clássica, a que levará mais tarde Erasmo a constatar: Se cabe a um bom cristão detestar os judeus, então somos todos bons cristãos" (POLIAKOV, 1979, p. 106).

Em Portugal, o reinado de D. Manuel é um claro exemplo da complexa tensão entre cristãos e judeus. Quando da expulsão dos judeus a mando dos Reis Católicos, Portugal receberia cerca de 600 famílias judias. Ao impor-lhes condições financeiras para entrada e passagem pelo reino português -, Portugal retirou proveito financeiro da expulsão espanhola. Porém, em 1496, fruto da celebração do contrato matrimonial, cessa o zelo português para com os judeus e honra-se o pedido dos Reis Católicos. Consciente da perda eminente, o rei luso obstrui a medida anterior: exclui outros portos de saída que não Lisboa e decreta carecimento de autorização real para saída dos judeus sob pena de confisco dos bens (TAVARES, 1997). Há um desejo de manutenção da presença judaica: Espanha concede quatro meses para a retirada dos judeus. Portugal dez (SARAIVA, 1985).

Ante o exposto, é legítimo afirmar que D. Manuel não pretendia prescindir de uma mão de obra tão qualificada, nem incorrer no risco de perda de financiamento, tanto a médio como a longo prazo. Relembre-se que Portugal se inseria num quadro político e económico de expansão ultramarina no qual os judeus assumiam um papel de destaque, senão mesmo imprescindível para a consecução dos objetivos régios. Neste sentido, a política de conversão foi uma das medidas encontradas para legitimar a manutenção hebraica em solo nacional. 
Fechados todos os portos para a evasão judaica, e criados impedimentos legais para a fuga dos crentes em Moisés, o rei decreta que a saída do reino teria que se cumprir pelo porto de Lisboa. Aquando da chegada dos judeus a Lisboa o monarca força-lhes o batismo. Este batismo em massa geraria o termo 'aboab' cuja aceção remete para o convertido em pé. Paralelamente, cumpre um episódio sombrio, retira-lhes a custódia dos filhos cuja idade fosse inferior a catorze anos para serem educados por cristãos, e só a recuperariam mediante conversão. Kayserling revela: "os pais, levados ao desespero, vagavam como dementes, as mães resistiam como leoas. Muitos preferiam matar os filhos com as próprias mãos; sufocavam-nos no último abraço ou atiravam-nos em poços ou rios, suicidando-se em seguida" (1971, p. 112).

Com o processo de mesclagem dos judeus na sociedade cristã pretendeu-se a abjuração da fé na Lei de Moisés. Na receção das águas do batismo, o judeu partilharia da onomástica cristã e passaria a ser designado por cristão-novo. O seu histórico seria apagado. O neófito assumiria os costumes e as regras da convivência cristãs - pondo-se término às comunas. Também os lugares sacros e de culto judaicos como as sinagogas foram destruídos. O converso não poderia trocar ou vender toda a sua fazenda e, em caso de deslocações e negócios no estrangeiro, a sua família deveria permanecer em território nacional servindo de garante do seu retorno. Não era permitido o consórcio entre cristãos-novos. Como incentivo à conversão permitia-se a manutenção dos cargos, recuperação da guarda dos filhos e possibilidade de retorno à antiga morada. Também a isenção de impostos pesados seduzia os conversos. A inquisição à idoneidade da sua fé era aliviada por vinte anos ${ }^{\mathrm{vi}}$.

Nesse quadro relacional, a tribo judaica entra em conflito com a identidade legitimadora que dá origem a uma sociedade civil, ou seja, um conjunto de organizações e 
instituições, bem como uma série de atores sociais estruturados e organizados que, embora às vezes de forma conflituosa, reproduzem a identidade que racionaliza as fontes de dominação estrutural (CASTELLS, 2007, p. 5).

As sinergias vigentes obrigaram à construção de identidades de resistência (CASTELLS, 2007; CALHOUN, 1994). As identidades em apreço criam-se por atores que se encontram em posições/condições desvalorizadas e/ou estigmatizadas pela lógica da dominação, construindo, assim, trincheiras de resistência e sobrevivência com base em princípios diferentes dos que permeiam as instituições da sociedade, ou mesmo opostos a estes últimos (CASTELLS, 2007, p. 4-5) ${ }^{\text {vii }}$.

Apesar da insistência judaica em pelejar para ter sucesso no país em que residem, tanto em tempos mais remotos como no período do Holocausto, o estigma e a marginalização social, a perda de mobilidade, a privação de bens e de fazendas adensariam o desejo de fuga que muitos judeus colocaram em prática (cf. RUNA \& PINTO, 1997, p. 15). Para esta evasão, muito contribuíram alguns factores: o bilinguismo; o engenho e intelecto; a capacidade de transformar o seu património em bens fáceis de transportar tais como letras de câmbio.

No discurso memorialista de Lezjon, algumas destas características são recuperadas. A respeito da proficiência linguística, leia-se: “aqueles de nós que eram judeus falavam iídiche em casa, polaco em público e hebraico na escola religiosa ou sinagoga. Eu também aprendi um pouco de alemão" (p. 29); “Fiz amizade com (...) uma bonita rapariga húngara (...) aprendi a falar húngaro fluentemente apenas para poder comunicar com ela" (p. 141). No que é atinente ao labor, atente-se no seguinte recorte: “às vezes, [Schindler] gesticulava para nós os três (...) e dizia que éramos «uma família de operadores de máquinas». Com um certo sentimento de orgulho, ele acrescentava 
"especialistas»" (p. 113). Por seu turno, a obra O caderno do avô Heinrich revela que a população ficou privada de professores quando os judeus se mudaram para o gueto. Pela voz de uma personagem não judia escuta-se:

Semanas depois de o Józef ter ido viver para o ghetto, a minha vida voltou a ser solitária e triste, como nos primeiros tempos em que vivi na Polónia. Já não tinha o meu amigo Józef para jogar à bola e conversar, mais de metade dos alunos da minha turma tinham sido obrigados a mudar-se para o gueto, havia mais disciplinas que precisavam de novos professores, já que aos antigos, porque eram judeus, não lhes era permitida a saída do gueto para irem trabalhar (TOMÉ, 2013, p. 37).

\section{0 poder como exercício}

Os ambientes ficcionais criados n'O rapaz do caixote de madeira e n'O caderno do avô Heinrich são bastante densos sob o prisma da violência. Para além das restrições e das condições impostas aos judeus, tais como a proibição de compra de terras (p. 28), a inferioridade racial (um judeu devia sair do passeio sempre que passasse um alemão) (p. 56) ou o impedimento de acesso a lugares e a transportes públicos (p. 48), a narrativa descreve, ainda, uma enorme violência física. Lejzon narra:

Os soldados alemães agiam com impunidade. Nunca se podia prever o que fariam a seguir. Saquearam empresas judaicas. Expulsaram judeus dos seus apartamentos e mudavam-se para lá, confiscando os pertences dos proprietários originais. Os judeus ortodoxos eram especialmente visados. Os soldados agarravam-nos na rua, espancavam-nos e cortavam-Ihes as barbas e os canudos de cabelo conhecidos como paiot, apenas pelo gozo, ou o que consideravam gozo (LEJZON, 2013, p. 49). 
O espancamento e o vexame eram estendidos a quem partilhasse da causa judaica. Na obra de Conceição Tomé, o avô foi um homem corajoso que "fez parte da resistência polaca que, clandestinamente, ajudou, desde o início da guerra, os judeus. Participou em reuniões, distribuiu boletins, ajudou a salvar muitas crianças judias" (LEJZON, 2013, p. 74). Por esse motivo seria agredido:

quando procurei olhar o rosto do meu pai, vi que ele estava estendido no chão da salinha derrubado por um murro certeiro no nariz. As botas engraxadas dos dois soldados irrompiam furiosas contra o seu corpo, sem que os agressores se preocupassem com o local onde batiam. 0 meu pai gemia baixinho e enroscava-se no próprio corpo à procura de proteção. As minhas unhas cravaram-se na porta e não pude conter as lágrimas (LEJZON, 2013, p. 41).

Conforme a história de Lejzon desvenda, bastava ser judeu para que toda a violência passasse impune. Note-se que a personagem, quando tinha idade inferior a doze anos, não usava a braçadeira que o identificava como judeu e podia escapar ao destratamento:

de certa forma, utilizava os seus próprios estereótipos contra eles, já que não havia nada em mim que tornasse óbvio que eu era judeu. Com o meu cabelo espesso e escuro, e os meus olhos azuis, parecia-me com muitos outros rapazes polacos. De vez em quando, sentava-me num banco do parque só para provar que podia fazer o que queria, resistindo aos nazis à minha própria e limitada maneira (LEYSON, 2013, p. 57).

No entanto, a situação muda quando responde ao soldado alemão, revelando que é judeu: "respondi que sim. Eles esbofetearam-me, furiosos por terem presumido que eu era uma criança "normal". Felizmente, não levaram a agressão mais longe do que as bofetadas" (idem, p. 64). 
Apesar de se tratar de um relato ficcional, o segmento narrativo interpela o leitor e, implicitamente, incita-lhe a reflexão sobre a justiça do discurso nazi, propondo-lhe a revitalização dos seus ambientes cognitivos (Azevedo e Sardinha, 2013). Mais adiante, o narrador tornará evidente a sua ideologia (REIS; LOPES, 2011, p. 209):

$\mathrm{Na}$ realidade, esse alegado contraste não era de todo real. Muitos judeus tinham olhos azuis e cabelos louros, e muitos alemães e austríacos, incluindo Adolf Hitler, tinham olhos e cabelos escuros. Mas o dogma nazi metia os judeus todos no mesmo saco, como o odiado inimigo dos arianos. Para eles, ser judeu não tinha a ver com aquilo em que acreditávamos, mas com a nossa alegada raça. Aquilo não fazia sentido para mim e cheguei a perguntar-me como podiam os próprios nazis acreditar em tais contradições. Se se tivessem dado ao trabalho de olhar realmente para nós, teriam visto seres humanos tal e qual como eles: alguns com olhos azuis, alguns com castanhos. Teriam visto famílias tal e qual como as suas: filhos e filhas, mães e pais, médicos, advogados, professores, artesãos e alfaiates, indivíduos de todas as classes" (ibidem, p. 71-72).

Em tempos mais remotos, também a Europa assistiu a uma escalada de violência contra o povo semita num movimento que se expandiu do centro do Velho Continente à sua periferia. Conforme sistematiza Ortiz, "con referencia a los siglos XII y XIII, época de plenitud y armonía; en el XIV el ambiente se ensombrece: el hambre, la peste, el cisma, las luchas religiosas y sociales sacuden Europa entera, anunciando el fin de una edad y el difícil alumbramiento de otra nueva" (ORTIZ, s.d., p. 15). Em Espanha, verifica-se uma deterioração das relações cristão-judeu. As datas de 1328, 1367 e 1369 registam episódios de violentas clivagens. Todavia, o maior seria

el asalto y destrucción de la judería de Sevilla (junio de 1391), seguida de la muerte o el bautismo forzado de la mayoría de sus moradores. Con la rapidez del rayo se propagó, sin respetar las fronteras políticas, por otras poblaciones de Andalucía, Levante y Cataluña; fueron asaltadas las 
juderías de Valencia, Barcelona, Gerona, Lérida y otras muchas ciudades" (idem).

Em Sevilha, este episódio foi especialmente violento:

las masas sevillanas, fanatizadas, se echaron a la calle y asaltaran la importante judería de la ciudad. Unas cuatro mil personas fueron asesinadas, debiendo convertirse al cristianismo casi todas las restantes que en ella habitaban para poder salvar sus vidas. La judería dejó de existir y sus casas, tiendas y sinagogas fueron entregadas a los caballeros cristianos (BLÁZQUEZ MIGUEL, 1988, p. 14).

\section{Imagótipos literários: o judeu e o nazi}

Para a construção de uma imagem pejorativa do judeu, é de enaltecer o contributo da literatura apologética e panfletária. Lejzon partilha a propaganda nefasta concretizada pelo regime nazi: "Os judeus viram-se confrontados com todos os tipos de caricaturas insultuosas. Apareceram cartazes humilhantes, tanto em polaco como em alemão, retratando-nos como criaturas grotescas e imundas, com grandes narizes aduncos" (2013, p. 48). Estes jogos de alterização não são apanágio do séc. XX e encontram ecos ao longo da história. Aliás, cabe referir que a ideologia antissemita surge ao longo do século XIII, a par da imposição de determinados dogmas definidos no IV Concílio de Latrão. Por exemplo, foi neste importante concílio que se definiu o dogma da Transubstanciação, foi aí que se fixou o número dos sacramentos, foi aí, finalmente, que se estipulou a obrigatoriedade dos judeus se diferenciarem dos cristãos por símbolos aplicados nas suas roupas (AFONSO, 2006, p. 103). 
Porém, se durante o século XIII, as contendas entre judeus e cristãos se prendiam, sobretudo, com a interpretação das escrituras sagradas, a espaços vão surgindo configurações explícitas da imagem do judeu e que são ipsis litteris as imagens recuperadas pelo discurso nazi:

Curiosa também é a referência constante ao trajo negro dos rabis judeus: "Mais logo outro judeu muj uelho uistido em panos negros como o primeiro»; "Mais logo se leuantou outro judeu uelho e amarello em no rosto com seu grande tabar do preto e sua barua muy longua»; " Elogo se leuantou outro judeu muy uelho e muj magro ben assy uistido de doo come os primeiros seos cabellos longos em na cabeça»; "outro reby judeu com sua cabeça toda calua e seu narjz longo sem mesura uestido asy come os outros. E a sua barua muj espessa (TAVARES, 2000, p. 80).

Conforme salienta Tavares (2000), ao longo do século XIV, a literatura apologética, tenderá a diluir a ênfase colocada na discussão das escrituras sagradas, e a infixar sobre o judeu uma imagem próxima da de Satanás:

Este estilo de apologética desapareceria no período moderno, onde a argumentação com base nos comentários bíblicos e nos textos rabínicos daria lugar à transmissão de topoi distorcidos sobre o outro, o judeu. Agora aparecia a semelhança física com Satanás, a referência à menstruação e a outros estereótipos que nada tinham a ver com a apologética medieval e que assentavam num imaginário popular, cujas raízes talvez se devam procurar no exterior da Península lbérica (TAVARES, 2000, p. 86).

Por vezes, a minoria religiosa judaica chega a partilhar o epíteto de 'cão' com o muçulmano $^{\text {viii }}$ - facto que adensa a impureza judaica e a sua bestialização ${ }^{\mathrm{ix}}$. A trama de Conceição Tomé traz a cena os três tópicos aqui referidos: o carácter animal da tribo judaica, a imagem prototípica do judeu ${ }^{\mathrm{x}}$ e a propaganda nazi. Se não, leia-se: 
Reparei num papel caído no chão. Era um panfleto das SS, a polícia nazi. Na parte superior, a cruz suástica, seguida de uma imagem de um judeu velho e de longas barbas, de mão dada com uma criança. A mensagem estava escrita com letras vermelhas, sob a fotografia do judeu, como se fosse uma legenda: «o homem inferior com as suas mãos e os seus pés e a sua espécie de cérebro, com os seus olhos e a sua boca que parecem pertencer à espécie humana é, apesar disso, de outra muito diversa: é um criatura horrível... situada, pelo seu espírito e pela sua alma, a um nível inferior ao do animal»» (TOMÉ, 2013, p. 57-58).

As narrativas convocadas centram-se, especialmente, na figura do judeu, na sua condição e nas ações de resistência perpetradas pelo mesmo. No entanto, a espaços, existem contraimagens e a literatura torna visível uma cartografia cultural pondo em diálogo a diferença, a diversidade e a "outridade" (SIMÕES, 2011). Nesses casos, o relato adensa o contraste entre as condições judaicas e as vidas alemãs:

através das cercas de arame farpado que delimitavam o campo, eu olhava para fora e, por vezes, via os filhos dos oficiais alemães a marcharem para trás e para a frente, nos seus uniformes da Juventude Hitleriana, a entoar canções em louvor do Führer, Adolf Hitler. Eram tão exuberantes, tão cheios de vida, enquanto, a uns escassos metros deles, eu me arrastava, exausto e deprimido, lutando para sobreviver mais um dia. Só a espessura do arame farpado separava a minha vida no inferno das suas vidas de liberdade (...) (LEYSON, 2013, p. 102).

Igualmente curiosas são as sequências narrativas que permitem ao leitor saber que as inimizades são construídas e favorecidas pelo contexto. Mais, permitem, ainda, saber que o ódio não é característica imputável apenas ao alemão e ao nazi. Na narrativa de Conceição Tomé, a irmã de Józef lança-lhe o seguinte reparo: “Não sei se a mãe vai achar boa ideia tu trazeres esse amigo para nossa casa... A palavra amigo saiu-lhe da boca carregada de ironia e desprezo" (TOMÉ, 2013, p. 31). Na mesma diegese, outras 
passagens permitem inferir a inimizade pelo alemão que passa na rua: "havia homens que resmungavam comentários. Não deviam ser muito elogiosos, não só pelas expressões dos rostos, mas também porque, às vezes, alguns polacos cuspiam para o chão" (idem, p. 30).

A relativização adquire especial preponderância quando personagens como Amon Goeth e Schindler se leem de forma oponível. Ambos são alemães, no entanto, Goeth após entrar na enfermaria decide balear todos os enfermos judeus sem qualquer razão justificativa (p.98). O SS Hauptsurmführer também decide, para seu prazer, chicotear com regularidade os judeus (p.99-100). Por sua vez, Schindler é descrito com apreço e admiração. No término da narrativa, Lejzon escreve, em claro tom de agradecimento:

Na sua qualidade de nazi influente, Schindler tinha escolha. Podia ternos abandonado vezes sem conta, pegado na sua fortuna e fugido. Podia ter concluído que a sua vida dependia de nos fazer trabalhar até cairmos mortos, mas não o fez. Em vez disso, pôs a sua própria vida em risco a cada vez que nos protegia, por nenhuma outra razão além de que era a coisa certa a fazer. Não sou um filósofo, mas acredito que Oskar Schindler define heroísmo (2013, p. 162).

\subsection{O mundo em arame farpado}

O cenário no qual decorre toda a ação é, igualmente, afetado e moldado. Segundo Le Goff (1988), a cidade abriga os que Ihe são comuns e que possuem um papel tangencial no que diz respeito à vivência quotidiana: os nativos da região, aqueles que partilham crenças e valores morais e cívicos. Assim, é possível antecipar a cidade como um organismo algo intransigente, no qual não é permitido que os seus habitantes vivam 
em desajuste com as leis institucionais e religiosas vigentes sem seres vistos ou tidos como marginais.

Assim, como que consubstanciando um mecanismo de defesa, adotado em relação a quem ameace a saúde e a ordem públicas, assiste-se ao fenómeno de gettare, cujo étimo transporta a aceção de 'lançar' ou 'despejar'. Sendo assim, despejar, é pôr para fora e o despejo significa tanto o objeto como o resultado desta ação, e aqui podemos ler o ghetto (PEREIRA; CRUZ, 2004).

D. Dinis ensaiou a segregação espacial entre credos, e D. Pedro I selou a obrigatoriedade da mesma. Assistiu-se, assim, à correspondência física do cativeiro em que vivem metaforicamente os judeus. Com feito, os judeus passaram a agrupar-se em comunidades, vulgo comunas, vivendo em ghettos que consubstanciam o seu castigo. Conforme repara Afonso, "[os cristãos] mantinham os judeus contemporâneos sob sujeição, fechados em ghettos, em autêntico cativeiro, como prova perene do castigo divino perante o seu erro" (2006, p. 102).

Dentro de tais ghettos, o judeu devia obedecer às imposições que lhe vetavam as saídas noturnas e lhe impunham um recolher obrigatório; devia manifestar zelo na relação com o cristão, especialmente nas situações tidas como ofensivas ante a moral cristã, tais como a posse de criados cristãos; e proceder ao pagamento de impostos, superiores aos montantes pagos pelos seguidores de Cristo.

Em pleno séc. $\mathrm{XX}$, o cronótopo d'O rapaz do caixote de madeira partilha o crescendo da segregação na Polónia de 1938: "as restrições multiplicavam-se rapidamente. Parecia que não havia quase nada que os judeus ainda estivessem autorizados a fazer" (LEYSON, 2013, p. 48). As restrições enfocadas, depressa evoluem para limitações espaciais - como que antecipando a criação de ghettos: "Já não nos era 
permitido sentarmo-nos nos bancos dos parques. Depois fomos completamente banidos de todos os parques. Foram colocadas cordas dentro dos elétricos, demarcando os lugares reservados aos gentios, os polacos não judeus, na frente dos carros, dos destinados aos judeus, na retaguarda" (idem).

Volvidos dois anos, "em maio de 1940, os nazis começaram a implementar uma política destinada a "limpar" Cracóvia" (ibidem, p. 64) e apenas 15 mil judeus foram autorizados a permanecer na cidade. Em dezembro do mesmo ano,

começaram a circular rumores. Seria construído um gueto numa secção da zona sul de Cracóvia conhecida como Podgórze. A área seria cercada de muros altos e os poucos portões seriam continuamente vigiados por alemães. Todos os judeus que ainda restavam na cidade seriam forçados a viver no gueto e não poderiam deixá-lo a menos que lhes fosse dada permissão pelos alemães (LEYSON, 2013, p. 66-67).

Na obra O caderno do avô Heinrich, pelos olhos do outro, de uma personagem que não é judia, são dadas a conhecer as condições do gueto polaco: "As casas estavam fechadas. (...) Na verdade, todo o gueto era agora um beco sem saída. Um conjunto de ruas sem início e sem fim, um caminho para nenhum lugar, um parêntese na geografia da cidade" (2013, p. 45). Após um primeiro olhar que dá conta de um cenário fantasmagórico, Heinrich encontra judeus e a desolação paisagística estende-se ao elemento humano:

apenas alguns velhos deitados na borda dos passeios, alguns sujos de urina, a dormir, enroscados como bebés, no frio da pedra. Meia dúzia de homens a conversar em voz baixa, algumas mulheres à entrada dos prédios a catar piolhos a crianças chorosas. (...) O rapaz caminhava apressadamente, levando, pela mão, duas meninas de cerca de quatro anos, tão esfarrapadas como ele, a mesma magreza e a mesma tristeza nos rostos amarelados (TOMÉ, 2013, p. 45-46). 
Dentro de muros, segundo a narração de Lejzon, os judeus batalhavam pela preservação dos seus valores, mostrando dignidade e um espírito resiliente: "apesar de termos tudo contra nós, todos continuámos determinados a mostrar respeito e decência uns para com os outros. Preservando a nossa humanidade, valorizando o nosso legado, lutámos contra a depravação dos nazis com formas subtis de resistência" (2013, p. 72). Cada indivíduo fazia valer a sua singularidade e o seu métier: "os rabinos resistiam celebrando serviços religiosos nos dias sagrados judaicos. Médicos e enfermeiros resistiam lutando para salvar a vida dos doentes e feridos, e trazendo novas vidas ao mundo. Atores e músicas resistiam criando palcos improvisados (...) onde apresentavam peças e sátiras, e davam concertos" (idem, p. 72).

Em tempos idos, encontram-se exemplos do espírito combativo judeu. A vivência em comunas - apesar de não ser a situação ideal porque o judeu sempre procurou a ascensão dentro da sociedade portuguesa -, permitiu aos seguidores de Moisés ter um espaço físico no qual podiam assegurar a manutenção das suas tradições e sistemas simbólicos. Pela vivência em ghetto preservavam a sua intimidade, e estimularam a autogestão e evitaram a completa assimilação. Tinham uma sinagoga, que por vezes funcionava não tão-só como lugar de culto, mas também como escola. A lei régia protegia o seu culto. Segundo as Ordenações Afonsinas, os judeus não podiam ser convertidos pela força e, além disso, as mesmas ordenações permitiam que ao Sábado, dia santo da religião mosaica, os judeus não fossem obrigados a participar em tribunal (SARAIVA, 1985).

Esse desejo de preservação identitária e histórica está igualmente implícita n’A História de Erika. Note-se que a narradora, que concretiza um relato de pendor 
autobiográfico, existe sem existir. Dito de outra forma, não sabe o dia em que nasceu, que nome lhe deram, em que cidade ou país veio ao mundo ou se teve irmãos (cf. ZEE, 2014, p. 11). A narrativa evidencia um completo desenraizamento social e permite perceber-se, em certa medida, uma vitória nazi sobre a tribo judaica. A narradora jamais recupera da sua amputação histórico-social e, sob o signo da emoção, interpela várias vezes o leitor com hipóteses sobre a história dos seus pais: "Teria murmurado o meu nome enquanto me envolvia no calor de uma manta? Ter-me-ia coberto a cara de beijos enquanto me dizia que me amava? Teria chorado? Teria rezado?" (idem, p. 17).

O discurso visual desta narrativa reproduz um episódio derradeiro na história dos guetos: a transição destes espaços para os campos de extermínio. Em tons sépia, a primeira moldura de duas páginas apresenta uma chusma sem expressão, de rostos voltados para baixo, em claro sinal de humilhação e de sofrimento. A multidão em apreço é conduzida por soldados que, em conjunto, com paredes e com barricadas de arame farpado Ihes restringem os movimentos. Poeticamente, os tons enegrecidos e densos, a presença do céu completamente nublado e a ausência de bebés nos seus carrinhos portam a mensagem da impossibilidade de vida e do pulsar da morte.

No relato de Leyson, quando se dá a mudança do gueto para os campos de extermínio, a personagem fica desolada quando percebe que fora de muros a vida continua igual e que a carnificina se concretiza, sobretudo, pela total indiferença do cidadão comum:

Quando saí do gueto, com os seus muros coroados de lápides, e comecei a caminhar pelas ruas de Cracóvia, fiquei atónito ao verificar que a vida parecia igual ao que era dantes. Era como se eu estivesse num túnel do tempo... ou como se o gueto ficasse noutro planeta. Pasmei para as pessoas limpas e bem vestidas, atarefadas de um lado para o outro. 
Pareciam tão normais, tão felizes... Não saberiam o que nós tínhamos sofrido, a uns escassos quarteirões de distância? Como poderiam não saber? Como podiam não ter feito nada para nos ajudar? Um elétrico parou e os passageiros embarcaram, alheios à nossa presença. Não manifestaram absolutamente nenhum interesse em quem éramos, para onde íamos ou porquê. Que a nossa miséria, o nosso confinamento e a nossa dor fossem irrelevantes para as suas vidas era simplesmente incompreensível (LEYSON, 2007, p. 92-93).

O episódio destacado recupera, sob o prisma da intertextualidade e dos altos valores humanos, a narrativa d'A História de Erika. Tanto Lezjon como os pais da judia que a atiram para fora do comboio - revelam uma ingénua esperança na humanidade ao acreditar que o homem não-judeu fará aquilo que é certo, amparando o judeu neste momento de grande aflição, superando a barreira religiosa.

\section{Considerações finais}

As obras $O$ rapaz do caixote de madeira, $O$ caderno do avô Heinrich e $A$ História de Erika concretizam uma literarização da experiência do Holocausto. Através destes relatos, alguns de pendor autobiográfico - como o de Lezjon e o de Erika ${ }^{\text {xii }}$-, o leitor acede à encenação literária do que foi o drama judeu durante os anos precedentes e subsequentes à Segunda Grande Guerra.

O exercício aqui concretizado logrou dar a conhecer que algumas das imposições concretizadas aos judeus do século XX recuperaram, e reconfiguraram, exercícios de poder legitimados em desfavor dos judeus em alguns contextos espácio-temporais, tais como o português - especialmente entre os séculos XIII a XVI. 
Para além de, implicitamente, se ter enaltecido a capacidade que a Literatura possui de produzir conhecimento e de dialogar hermenêuticamente com outras áreas de saber, favoreceu-se, igualmente, a virtuosidade da Literatura como lugar no qual se propicia, com enorme propriedade, a sociabilidade, a sensibilidade para a alteridade, a abertura ao diálogo com o outro, o desdobramento para outras realidades possíveis.

Num tempo em que emergem conotações pejorativas em relação à religião, ao imigrante, ao que é alheio e a Europa se fecha progressivamente, vale a pena repensar as dimensões das relações humanas. Neste sentido, e fechando em jeito de reflexão, podem ler-se as palavras de Lejzon que partilha uma memória da sua vida na América: "espanteime quando o motorista parou o autocarro e veio ter comigo. "Não pode sentar-se aí», disse ele. "Os bancos da retaguarda são para os negros». (...) As suas palavras atingiramme como um bofetão. (...) De repente, voltei à Cracóvia, quando os nazis ordenaram que os judeus viajassem na retaguarda do autocarro" (2013, p. 152).

\section{Referências}

AFONSO, L. U. Iconografia judaica em Portugal (séculos XIV-XV). Cadernos de Estudos Sefarditas. 6, p. 101-131. 2006.

AZEVEDO, F.; SARDINHA, M. G. Didática e práticas - a língua e a educação literária. Guimarães: Opera Omnia, 2013.

BLÁZQUEZ MIGUEL, J. La inquisición. Madrid: Ediciones Penthalón, 1988.

CALHOUN, C. (coord.). Social theory and the politics of identity. Oxford: Blackwell, 1994.

CASTELLS, M. O poder da identidade. Lisboa: Fundação Calouste Gulbenkian, 2007.

HERCULANO, A. História da origem e estabelecimento da inquisição em Portugal. Tomo I. Venda Nova: Livraria Bertrand, 1975. 
KAYSERLING, M. História dos judeus em Portugal. São Paulo: Pioneira, 1971.

LE GOFF, J. Por amor às cidades - conversações com Jean Lebrun. Tradução Reginaldo Carmello Corrêa de Moraes. São Paulo: Edunesp, 1988.

LEYSON, L. O rapaz do caixote de madeira. Lisboa: Editorial Presença, 2013.

ORTIZ, A. D. Los Judeoconversos en España y América. Madrid: Ediciones Istmo, s.d.

PEREIRA, M. R.; CRUZ, A. L. Mancebias e judiarias - espaços de segregação na cidade portuguesa (séc. XIV a XVII). Revista Territórios e Fronteiras, 5 (1), 133-154. 2004.

POLIAKOV, L. De Cristo aos Judeus da Corte. História do anti-semitismo I. São Paulo: Perspectiva, 1979.

REIS, C.; LOPES, A. C. Dicionário de narratologia. Coimbra: Almedina, 2011.

RUNA, L.; PINTO, M. C. T. Vivências de uma comunidade cristã nova no século XVI: Castelo de Vide. Patrimónia: Identidade, Ciências Sociais e Fruição Cultural, 3, 11-22. 1997.

SANTOS, B. S. Modernidade, identidade e a cultura de fronteira. Revista Crítica de Ciências Sociais, 38, 11. 1993.

SARAIVA, A. J. Inquisição e cristãos-novos. Lisboa: Editorial Estampa, 1985.

SIMÕES, M. J. (coord.). Imagotipos literários: processos de (des)configuração na imagologia literária. Coimbra: Centro de Literatura Portuguesa, 2011.

SPENCE, J. God's Chinese Son: the taiping heavenly kingdom of Hong Xiuquan. Nova Iorque: Norton, 1996.

TAVARES, M. J. F. Os judeus em Portugal no século XIV. Lisboa: Guimarães e Ca, 1979. Os judeus em Portugal no século XV, vol. I, Lisboa, FCSH- UNL. 1982. . A expulsão dos judeus de Portugal - conjuntura peninsular. Oceanos. Diáspora e Expansão. Os Judeus e os Descobrimentos Portugueses, 29, 10-20. 1997. . O difícil diálogo entre judaísmo e cristianismo. In: AZEVEDO, C. M. (dir.). História religiosa de Portugal. vol. 1. Lisboa: Círculo de Leitores, 2000. p. 69-86.

TOMÉ, C. D. O caderno do avô Heinrich. Lisboa: Editorial Presença, 2013. ZEE, R. V. A história de Erika. Lisboa: Kalandraka, 2007. 


\title{
Recebido em 29 de janeiro de 2019.
}

\section{Aceite em 27 de fevereiro de 2019.}

\begin{abstract}
' O Judaísmo (em hebraico: יהדות, Yahadút) é uma das religiões monoteístas com mais expressão. Do seu seio surgiu o Cristianismo e mesmo o Islamismo adotou vários elementos judaicos, reconhecendo Abraão e Moisés como profetas. Pelo Antigo Testamento acede-se a documentação escrita sobre a história judaica e sobre o seu povo - anteriormente designado por 'hebraico'. O documento sagrado divide-se em Torá ou Pentateuco, Livros Históricos, Livros Sapienciais e os Livros Proféticos. A língua que cumpriu grande parte da redação do Antigo Testamento e do Tanakhi foi, sobretudo, o aramaico, e em alguns dos textos mais recentes, dos últimos séculos a. C. utilizou-se também o latim. Outro compêndio fulcral é o Talmud que compila várias leis e tradições judaicas em 4 livros (63 tratados de questões éticas, históricas ou legais). Este último, não é reconhecido por toda a comunidade judaica, o seu estudo é encetado pelos judeus ortodoxos e conservadores. Recuperando o Antigo Testamento, os judeus são descendentes de Abraão e estabeleceram-se em Canaã - território que hoje tem correspondência geográfica com Israel - há 3800 anos. Devido a condições adversas registadas no séc. XVII a. C., migraram para o Egito e foram, ulteriormente, escravizados por 400 anos. Sob a liderança de Moisés, libertaram-se da escravidão e, após uma peregrinação de 40 anos, alcançaram a Terra Prometida. A mesma fonte descreve como o povo hebraico recebeu as Tábuas de Lei guardadas na Arca da Aliança e ainda a construção do Templo em Jerusalém. Em 587 a. C., ver-se-iam obrigados a abandonar a terra e fugiram para a Babilónia, mas, mais tarde, recuperariam a Terra Prometida. Concomitantemente, os judeus começaram a dispersar-se para o Egito e pela Índia. Em 70 a. C., o ataque das tropas romanas e a consequente destruição da cidade ditariam o início da diáspora forçada pela ausência de pátria.
\end{abstract}

ii No século XIV, esta clivagem religiosa - assumida pela tribo judaica que registava, em sentido ascendente, trinta e duas comunas no séc. XIV - originará um verdadeiro celeuma sobre a verdadeira religião. $O$ intuito de fundo é, numa facção, a conversão judaica pela abjuração da fé antiga e, na outra, a manutenção da fé judaica. Neste ponto, esgrimar-se-ão argumentos a favor de cada uma das crenças. Os judeus farão da argumentação de Nahmanides a sua pedra basilar. Por sua vez, os cristãos encetarão uma ampla produção intelectual em desfavor do judeu e da sua cegueira - onde a obra Pugio Fidei ressalta como expoente exemplar de intolerância cristã perante a ofensa judaica. $O$ resultado desta batalha religiosa e intelectual resvalaria, segundo Tavares, numa vitória cristã, dado que os judeus apareciam aqui sem argumentos suficientes e fortes para vencer as asserções da "católica rainha" que se baseava sempre na Sagrada Escritura e no texto hebraico, acabando os judeus por se calarem vencidos, mas não convencidos, pois não se convertiam ao cristianismo, ao contrário do gentio (TAVARES, 2000, p. 80).

iii O título estará relacionado com um episódio narrativo. O narrador revela: “Eu era tão pequeno que tinha de me empoleirar num caixote de madeira virado ao contrário para chegar aos comandos da máquina. Schindler parecia divertir-se imenso com isso" (LEYSON, 2013, p. 112).

iv Como Spence sistematiza: "Não temos conhecimento de um povo que não tenha nomes, idiomas ou culturas em que alguma forma de distinção entre o eu e o outro, nós e eles, não seja estabelecida... o autoconhecimento - invariavelmente uma construção, não importa o quanto possa parecer uma descoberta - nunca está totalmente dissociado da necessidade de ser conhecido, de modos específicos, pelos outros" (SPENCE, 1996, p. 172).

"Boaventura Sousa Santos escreve sobre o dinamismo dos processos identitários: "sabemos hoje que as identidades culturais não são rígidas nem, muito menos, imutáveis. São resultados sempre transitórios e fugazes de processos de identificação. Mesmo as identidades aparentemente mais sólidas como a de mulher, homem, país africano, país latino-americano, ou país europeu, escondem negociações de sentido, 
jogos de polissemia, choques de temporalidades em constante processo de transformação, responsáveis em última instância pela sucessão de configurações hermenêuticas que de época para época dão corpo e vida a tais identidades. Identidades são, pois, identificações em curso" (SANTOS, 1993, p. 11).

vi Porém, conforme repararia Herculano, o judeu, mesmo neófito, recebe o epíteto de converso, confesso ou marrano, "alcunha injuriosas, que na Idade Média equivalia a maldito" (HERCULANO, 1975) o que atesta a discriminação operada. Recupere-se ainda a literatura, e com ela a caracterização do Judeu lida em Gil Vicente no Auto da Barca do Inferno onde o judeu nem ao diabo interessa.

vii Ao longo dos séculos XIII e XIV, os judeus estavam bastante conscientes do volátil jogo social maquinado pelos centros de poder. Neste contexto antagónico, tiveram que trabalhar as suas teias de influência de forma a conseguir persistir na sociedade em que se inseriam. Esta inserção tende a variar consoante o poderio económico e social do indivíduo. Como aponta Saraiva (1985, p. 28), desde a primeira dinastia eram os hebreus os tesoureiro-mores do rei, bem como os seus banqueiros e arrematantes da cobrança de rendas. Nessa função de técnicos financeiros eram indispensáveis à Coroa. Também chega a ser amplamente notada "a presença dos judeus entre as elites, nomeadamente em tarefas que respeitam à organização e ao financiamento do Estado" (AFONSO, 2006, p. 109). Esta alta mestria, geralmente obtida por virtude da educação, adquire contornos sacros quando se lê no Talmud: "é proibido interromper o ensino numa escola mesmo que isso fosse necessário para conseguir a reconstrução do Templo" (TAVARES, 1982, p. 44). Há a consciência da educação como alavanca social. É a especialização que faz com que o judeu ascenda a cargos de prestígio, especialmente nas que carecem de saber científico, como a astronomia, economia e medicina - áreas de particular interesse para o judeu. Inteligente, e bilíngue por força das circunstâncias, o judeu dedica-se assim às disciplinas supramencionadas como atividades de eleição, conciliando a atividade primária com outras, descentrando a sua ação de uma rota profissional afunilada. Tavares escreve: "os judeus vivem, não só do comércio e do artesanato, mas também da agricultura e da criação de gado (...). Assim, nas suas hortas e quintais, nas quintas, pomares e vinhas, eles criam produtos hortícolas, cerealíferos e outros, que vendem nos açougues das comunas uns aos outros, e extra-comunidade, nos açougues cristãos" (TAVARES, 1982, p. 47).

viii Na obra A Peregrinação de Fernão Mendes Pinto, é recorrente a referência ao muçulmano como 'cão' símbolo de impureza. Na narrativa de Orhan Pamuk, My name is red, é debatida a razão do cão ser considerado um animal impuro: "so then, what's the actual reason for this animosity toward dogs? Why do you persist in saying that dogs are impure, and cleaning and puryfing your homes from top to bottom if a dog happens to enter? (...) Now, a dog is considered a bad omen (2004, p. 15-16).

ix Também a História de Erika reforça a imagem do judeu próxima da do animal: "Pergunto-me o que teriam sentido enquanto os levavam em manadas para a estação com outras centenas de judeus. Comprimidos num vagão para gado, de pé e sem se poderem mexer" (ZEE, 2014, p. 14).

' Segundo Lezjon, personagem principal d'O rapaz do caixote de madeira, "aos olhos dos nazis, nós, os judeus, éramos um único grupo odiado, o exato oposto do ideal louro e de olhos azuis dos "arianos" ouros" (LEYSON, 2013, p. 71).

${ }^{x i}$ Na obra em apreço, pode ler-se a seguinte nota do autor: "transcrição exata de um panfleto disponível em Grande Crónica da Segunda Guerra Mundial, II vol., Seleções do Reader's Digest, 1975, p. 165” (TOMÉ, 2013, p. 58).

${ }^{\text {xii }}$ A história é permitida pela existência extratextual de uma judia que partilha a sua memória. 